\title{
Identification of traffic-related metals and the effects of different environments on their enrichment in roadside soils along the Qinghai-Tibet highway
}

\author{
Hua Zhang a,b ${ }^{\text {a }}$ Zhaofeng Wang ${ }^{\mathrm{a}}$, Yili Zhang ${ }^{\mathrm{a}, \mathrm{c}, *}$, Mingjun Ding ${ }^{\mathrm{b}}$, Lanhui Li ${ }^{\mathrm{b}}$ \\ a Key Laboratory of Land Surface Pattern and Simulation, Institute of Geographic Sciences and Natural Resource Research, Chinese Academy of Sciences (CAS), Beijing 100101, China \\ ${ }^{\mathrm{b}}$ Key Laboratory of Poyang Lake Wetland and Watershed Research, Ministry of Education, Jiangxi Normal University, Nanchang 330022, China \\ c CAS Center for Excellence E Innovation in Tibetan Plateau Earth System Sciences, Beijing 100101, China
}

\section{H I G H L I G H T S}

- $\mathrm{Cr}, \mathrm{Zn}, \mathrm{Cu}, \mathrm{As}, \mathrm{Cd}$, and $\mathrm{Pb}$ in soils along the highway are related to the traffic.

- There are three distribution patterns of the traffic-related metals in soils.

- Regional differences had significant relationship with the enrichment levels.

- $\mathrm{Cd}$ was the prior metal and the TTH was the key area for soil environment monitoring.

\section{A R T I C L E I N F O}

\section{Article history:}

Received 20 October 2014

Received in revised form 10 March 2015

Accepted 13 March 2015

Available online 31 March 2015

Editor: F.M. Tack

\section{Keywords:}

Qinghai-Tibet highway

Road transportation

Soil pollution

Tibetan Plateau

Traffic-related metals

\begin{abstract}
A B S T R A C T
The road transportation could affect roadside soils environment detrimentally, including heavy metal enrichment. In order to identify and evaluate the enrichment of heavy metals resulted from road transportation on the Tibetan Plateau, the 11 heavy metals (V, Cr, Co, Ni, Cu, Zn, As, Cd, Rb, Pb and Tl) in the topsoil $(0-10 \mathrm{~cm}$ depth) from four sites along the Qinghai-Tibet highway were discussed in this study. Our results indicate that heavy metals such as $\mathrm{Cr}, \mathrm{Cu}, \mathrm{Zn}, \mathrm{As}, \mathrm{Cd}$ and $\mathrm{Pb}$ are related to road transportation. The content of most of these heavy metals in roadside soils decreased exponentially with the distance from the road, as did some of the Nemero Synthesis Indexes (PN values). The contamination factor for the traffic-related metals ranged from 0.56 (no pollution) to 5.67 (considerable pollution) and the Nemero Synthesis Indexes of these heavy metals ranged from 0.80 (no pollution) to 4.49 (severe pollution). Cd was of priority concern as it had the highest contamination factor. The highest PN value for these traffic-related heavy metals was found in soils at site TTH (alpine steppe). Although transportation contributed to the high contents of these traffic-related metals in roadside environments, regional differences such as wind and the terrain also had significant relationship with their enrichment in these roadside soils. The roadside distance at which there is a potential risk to livestock and wildlife from the contamination of soils by heavy metals should be determined scientifically along the Qinghai-Tibet highway, based on the different natural environments found in the region.
\end{abstract}

(c) 2015 Elsevier B.V. All rights reserved.

\section{Introduction}

Human activities such as industrialization, agricultural cultivation and the combustion of fossil fuels have dramatically altered the biogeochemical cycles of trace metals in the environment (Bashkin, 2003).

\footnotetext{
* Corresponding author at: Key Laboratory of Land Surface Pattern and Simulation, Institute of Geographic Sciences and Natural Resources Research (IGSNRR), Chinese Academy of Sciences (CAS), No. 11 A, Datun Road, Anwai, Beijing 100101, China.

E-mail address: zhangyl@igsnrr.ac.cn (Y. Zhang).
}

These activities have increased the mobility and availability of trace metals, significantly affecting their concentrations in the atmosphere, hydrosphere and soils, threatening both the natural environment and human health (Krishna et al., 2009; Wu et al., 2011; Mohiuddin et al., 2014). Road transportation has increased alongside rapid economic development, resulting in a sprawling road network in China. Road transportation is one of the most significant sources of heavy metal pollution and plays an important part in the biogeochemical cycles of trace metals (Liu et al., 2009; Khan and Kathi, 2014). The combustion of liquid fuels, vehicular abrasion and the weathering of track or road materials can release particles containing heavy metals (Suzuki et al., 2009; Chen et al., 
2010). Particles containing heavy metals such as Cd are released from vehicle tires and the burning of vehicle fuels (Chen et al., 2010), whereas the release of $\mathrm{Zn}$ may result from tire abrasion and lubricating oils (Adachi and Tainosho, 2004). Brake linings are one of the main sources of $\mathrm{Cu}$ (Adachi and Tainosho, 2004; Hjortenkrans et al., 2007); Pb is emitted from leaded fuels (Van Bohemen and Van De Laak, 2003) and Cr predominantly originates from oil residues and the abrasion of brake pads and tires (Zehetner et al., 2009). These particles are deposited into soils through dry and wet deposition, splashing and runoff (Werkenthin et al., 2014). Heavy metals can reside in soils for long periods of time as they tend to be non-degradable; they can damage the soil biota directly and also have an indirect toxic effect on plants by translocation from the plant roots to the aerial parts (Wang et al., 2013). Uptake by crop plants can threaten human health as the pollutants move up the food chain (Wiseman et al., 2014).

The enrichment of traffic-related heavy metals in roadside environments has been a focus of concern for more than 40 years, particularly the accumulation of heavy metals in soils. $\mathrm{Pb}$ in roadside environments was of great concern in the 1970s as a result of the use of leaded fuels (Chow, 1970; Motto et al., 1970). In addition to Pb, the heavy metals $\mathrm{Cd}, \mathrm{Cr}, \mathrm{Cu}, \mathrm{Ni}$ and $\mathrm{Zn}$ were later recognized and examined in roadside environments (Münch, 1993; Viard et al., 2004). Many other elements, such as As, Co, Sb, Se, Sr, V and the Pt group heavy metals, have been shown to have increased contents in soils near roads with heavy traffic (Thorpe and Harrison, 2008; Zhong et al., 2012). The Pt group heavy metals in particular have attracted much attention as roadside contaminants as a result of their use in catalytic converters (Bozlaker et al., 2013).

Many workers have found that the levels of heavy metals such as $\mathrm{Pb}$, $\mathrm{Cd}, \mathrm{Cu}, \mathrm{Zn}$ and $\mathrm{Cr}$ are related to road transportation (Chow, 1970; Münch, 1993; Viard et al., 2004) and an exponential or polynomial distribution of heavy metals in soils along highways has been reported (Nabulo et al., 2006; Ma et al., 2009; Yan et al., 2013). The amount and type of traffic and the condition of the road will affect the enrichment and distribution of heavy metals in roadside soils (Chen et al., 2010; Wiseman et al., 2013). There have been very few systematic studies of the enrichment of traffic-related heavy metals in the soils of the Tibetan Plateau, particularly the identification of traffic-related metals and their possible distribution patterns. Very few researchers have focused on the effects of different large-scale environments on the enrichment of traffic-related metals in roadside soils.

The Qinghai-Tibet highway offers favorable conditions for exploring the influence of highways on heavy metal enrichment in soils. Most of the area surrounding the Qinghai-Tibet highway has a well-preserved ecosystem in which the environment is extremely fragile and sensitive to outside influences ( $Y u$ and Lv, 2011). Even minor effects from human activities or climate change can lead to significant environmental damage (Klein et al., 2004). Apart from transportation, the environment in this region has few anthropogenic disturbances (Yan et al., 2013). The rapid development of road traffic due to freight transport and increasing tourism is exerting increasing pressure on roadside environments. The Qinghai-Tibet highway traverses several distinct landscapes with different climates, soils and types of vegetation, including alpine meadow and steppe ecosystems. Dynamic monitoring and assessment of the pollution of soils by traffic-related metals in these landscapes are important in the protection of these fragile ecosystems.

The main objective of the work reported here was to identify trafficrelated metals and to calculate their enrichment in the soils of different environments on the Tibetan Plateau. Based on a large-scale field investigation, we identified possible traffic-related heavy metal pollutants using statistical analysis, quantified the spatial relationships between the enrichment levels of these heavy metals and the distance to the road edge, and explored the relationship between the environmental differences and the enrichment levels of traffic-related metals in the roadside soils.

\section{Materials and methods}

\subsection{Study area}

The section from Golmud to Lhasa of the No. 109 National Highway (G109) (the Qinghai-Tibet highway) traverses several natural zones with different environmental characteristics. The various ecosystems along the highway include alpine shrub, alpine meadow, alpine steppe and alpine desert. It is the busiest transport route in the Tibetan Plateau, accounting for $90 \%$ of freight and $70 \%$ of passenger transport. It was built over 50 years ago and has a length of $1161 \mathrm{~km}$ and an average altitude of $>4000 \mathrm{~m}$. Most of the highway is designed for speeds up to $80 \mathrm{~km} / \mathrm{h}$ (Qinghai) and $60 \mathrm{~km} / \mathrm{h}$ (Tibet), although in some parts the design is for a lower speed of $45 \mathrm{~km} / \mathrm{h}$. About 1400 vehicles use the highway each day; $60 \%$ of the traffic is heavy trucks (Zuo, 2011). The climate of the area through which the Qinghai-Tibet highway passes belongs to the temperate/subfrigid continental zone, characterized by strong winds during the long cold winter, low rainfall in summer, and short spring and autumn seasons. This section of the highway crosses two main soil types: alpine steppe soil (Cryuborolls) and alpine meadow soil (Cryaquet) and a fraction of gray-brown desert soil (Gypsic Haplosalid).

The study area was located in the middle of the Golmud-Lhasa section of the highway and excluded an agricultural area to the north of Lhasa (the area from Damxung to Lhasa) to limit interference from other anthropogenic activities. The environment changes from alpine desert with low precipitation and rare vegetation (Golmud) to alpine meadow with low temperatures, abundant precipitation and a relatively heavy vegetation cover (Damxung). Table 1 gives details of the location and the physical features of the four different environments studied.

\subsection{Soil sampling strategy}

We used our previously published selection criteria for sampling sites (Zhang et al., 2012) to identify the sites at which to determine the distribution and enrichment of traffic-related metals in soils along the Qinghai-Tibet highway. Based on these criteria, the study area was divided into four sites: Golmud (GM), Tuotuohe (TTH), Nagqu (NQ) and Damxung (DX) (Fig. 1).

At TTH and NQ, three topsoil $(0-10 \mathrm{~cm})$ composite samples were collected at distances of $0,1,2,4,5,7,10,20,30,50,60,80,100,150$, 200 and $300 \mathrm{~m}$ from the roadside. For site DX, three composite samples were collected at $0,1,2,4,5,7,80,100,150,200$ and $300 \mathrm{~m}$ from the roadside, one composite sample at $10,20,50$ and $60 \mathrm{~m}$, and two composite samples at $30 \mathrm{~m}$ distance. For site $\mathrm{GM}$, three composite samples were collected at $0,1,2,4,5,7,10$ and $20 \mathrm{~m}$ from the road edge and one composite sample at 30, 50, 60, 80, 100, 150, 200 and 300 m distance. Each composite sample consisted of three to five subsamples, which were collected with a wooden shovel and packed into a polyethylene bag. In total, 168 soil samples were collected.

\subsection{Sample preparation and determination of the total heavy metal concentrations}

The soil samples were dried indoors at room temperature and then passed through a $2 \mathrm{~mm}$ nylon sieve to remove any stones and root debris. The method used to determine the total concentrations of heavy metals in the soil samples was based on that reported by Zhang et al. (2012). In brief, a 20-30 mg sample of air-dried ground soil was weighed and placed in a $15-\mathrm{mL}$ Teflon bomb. A $1-\mathrm{mL}$ volume of $\mathrm{HNO}_{3}$ and $1 \mathrm{~mL}$ of HF were added to the samples and they were placed on a hot-plate and evaporated to almost dryness at $150{ }^{\circ} \mathrm{C}$. The residue was dissolved in $1 \mathrm{~mL}$ of $\mathrm{HNO}_{3}$ and $1 \mathrm{~mL}$ of $\mathrm{HF}$ and then placed in a sealed stainless-steel container and heated in an electric oven at $190{ }^{\circ} \mathrm{C}$ for at least $24 \mathrm{~h}$. The sample was then placed on a hot-plate and evaporated 
Table 1

Location and physical features of the four different environments studied.

\begin{tabular}{|c|c|c|c|c|}
\hline Parameter & Golmud (GM) & Tuotuohe (TTH) & Nagqu (NQ) & Damxung (DX) \\
\hline Latitude & $35^{\circ} 59^{\prime}$ & $34^{\circ} 19^{\prime}$ & $31^{\circ} 35^{\prime}$ & $30^{\circ} 33^{\prime}$ \\
\hline Longitude & $94^{\circ} 49^{\prime}$ & $92^{\circ} 35^{\prime}$ & $91^{\circ} 47^{\prime}$ & $91^{\circ} 25^{\prime}$ \\
\hline Elevation (m) & 3302 & 4567 & 4539 & 4489 \\
\hline Soil type & Gray-brown desert soil & Alpine steppe soil & Alpine meadow soil & Alpine meadow soi \\
\hline Dominant species & Kalidium slenderbranch & Stipa purpurea & Kobresia pygmaea & Kobresia pygmaea \\
\hline Vegetation cover (\%) & $25-35$ & $30-40$ & $80-90$ & $85-95$ \\
\hline Soil texture & Sandy & Sandy loam & Clay & Clay \\
\hline $\operatorname{AAT}^{\mathrm{a}}\left({ }^{\circ} \mathrm{C}\right)$ & 6.44 & -2.93 & -0.02 & 2.57 \\
\hline $\mathrm{AAP}^{\mathrm{a}}(\mathrm{mm})$ & 37.82 & 390.05 & 401.78 & 426.20 \\
\hline $\operatorname{AAWS}^{\mathrm{a}}(\mathrm{m} / \mathrm{s})$ & 1.89 & 3.63 & 2.20 & 2.15 \\
\hline Soil pH & 7.52 & 8.05 & 7.82 & 7.48 \\
\hline Height of road bed $(\mathrm{m})$ & 0 & 2 & 0.8 & 1.1 \\
\hline Speed $(\mathrm{km} / \mathrm{h})$ & 80 & 80 & 45 & 60 \\
\hline
\end{tabular}

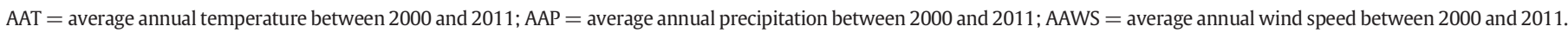

a Data from China's meteorological data-sharing service.

to almost dryness at $150{ }^{\circ} \mathrm{C}$. The residue was dissolved in $1 \mathrm{~mL}$ of $\mathrm{HNO}_{3}$ and evaporated to almost dryness at $150{ }^{\circ} \mathrm{C}$; this process was then repeated two more times. The final residue was digested once more by adding $2 \mathrm{~mL}$ of $\mathrm{HNO}_{3}$ and $3 \mathrm{~mL}$ of Milli-Q water, then placed in a sealed stainless-steel container and heated in an electric oven at $150{ }^{\circ} \mathrm{C}$ for at least $30 \mathrm{~h}$. A clear solution was finally obtained and this was diluted before analysis. The total concentrations of $\mathrm{V}, \mathrm{Cr}, \mathrm{Co}, \mathrm{Ni}, \mathrm{Cu}, \mathrm{Zn}, \mathrm{As}, \mathrm{Cd}, \mathrm{Rb}$, $\mathrm{Pb}$ and $\mathrm{Tl}$ were determined by inductively coupled plasma mass spectrometry (ICP-MS).

Standard reference materials (Geochemical Standard Soil GSS-1, GSS-3, GSS-5, GSS-6 and GSS-8) were used for quality assurance and quality control. The percentages of the 11 heavy metals recovered were: V, 99-115\%; Cr, 104-119\%; Co, 92-114\%; Ni, 108-118\%; Cu, 109-120\%; Zn, 94-106\%; As, 92-120\%; Cd, 88-120\%; Rb, 104-118\%; $\mathrm{Pb}, 96-118 \%$; and $\mathrm{Tl}, 95-122 \%$. Duplicate samples were analyzed simultaneously for $15 \%$ of the samples and the standard deviation was controlled to within $5 \%$ in each digestion procedure.

\subsection{Regression method}

A regression model was used to characterize the relationship between the content of heavy metals and the distance from the roadside using Origin 9.0 software (OriginLab, Northampton, MA, USA). The curve fitted with the lowest $\chi^{2}$ and highest $R^{2}$ values was taken as best model for predicting the relationship between the heavy metal content in the topsoil and the distance from the roadside.

\subsection{Contamination factors and Nemero Synthesis Index}

The contamination factor $(\mathrm{CF})$ was used to assess the enrichment of heavy metals in the soils and to measure the level of pollution along a particular route (Hakanson, 1980; Loska et al., 2004):

$\mathrm{CF}=C_{i} / S_{i}$

where $\mathrm{CF}$ is the contamination factor for heavy metal $i, C_{i}$ is the content of the heavy metal in the sample, and $S_{i}$ is the background content of heavy metal $i$. Based on Hakanson (1980), the CF was used to classify four levels of pollution: $\mathrm{CF}<1$ represents no or minimal pollution; $1 \leq \mathrm{CF}<3$ indicates moderate pollution; $3 \leq \mathrm{CF} \leq 6$ indicates considerable pollution; and $6<\mathrm{CF}$ indicates very high pollution.

To quantify the soil pollution status at the four different sites along the Qinghai-Tibet highway, Nemero Synthesis Index (PN value) calculations were carried out as follows (Li and Feng, 2010):

$$
\mathrm{PN}=\sqrt{\frac{\left(\frac{\mathrm{C}_{i}}{S_{i}}\right)_{\max }^{2}+\left(\frac{\mathrm{C}_{i}}{S_{i}}\right)_{\text {ave }}^{2}}{2}}
$$
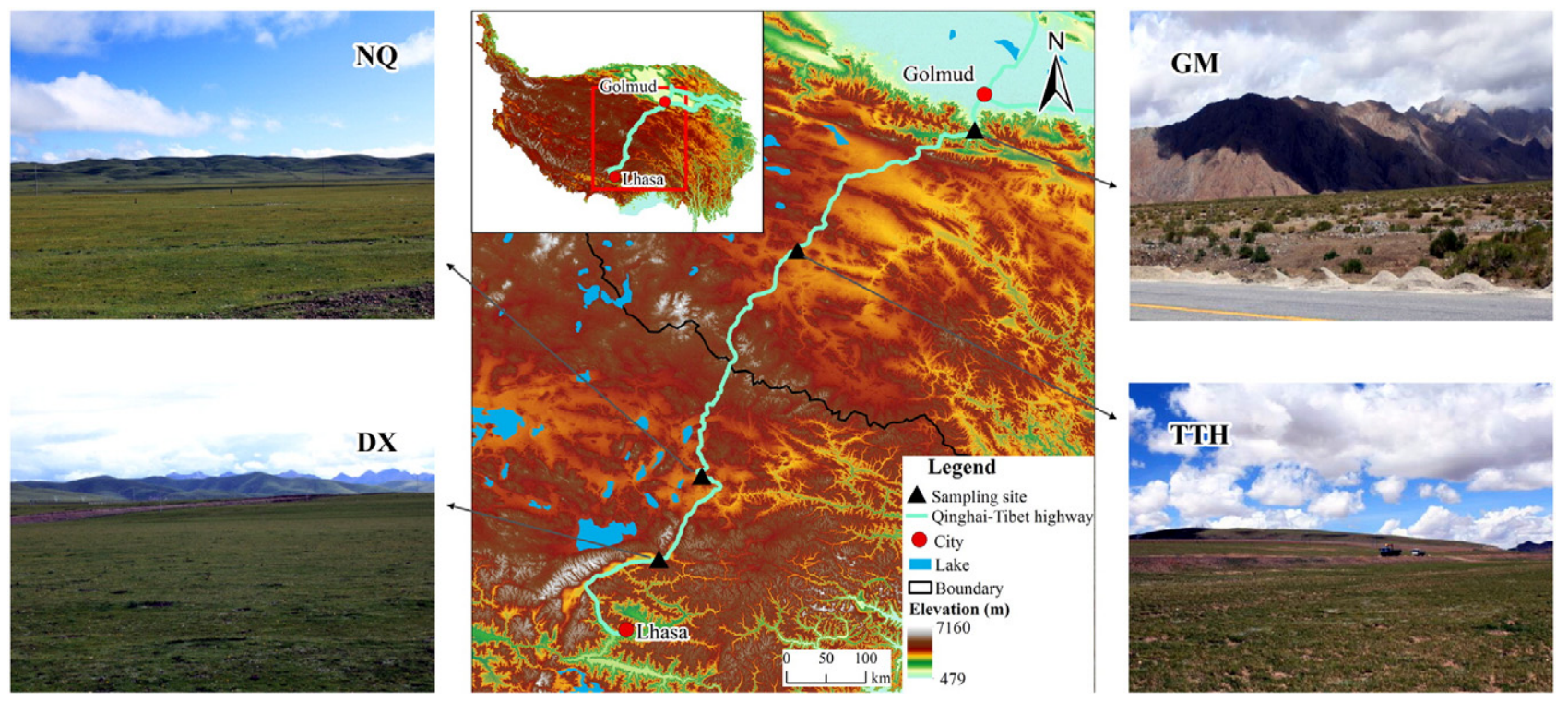

Fig. 1. Study area and sampling sites on the Qinghai-Tibet highway, China. 
where PN is the synthesis evaluation index for each sample, $C_{i}$ is the heavy metal content in each sample, and $S_{i}$ is the content of the reference heavy metal used for normalization in the sample. The content of the reference heavy metal was based on the soil background content at the four different sites.

Based on the Chinese soil environmental quality assessment standard for green-food production areas (State Development Center for Green-food of China, 2000), the PN value was graded into five categories: $\mathrm{P} \leq 0.7$, safety; $0.7<\mathrm{P} \leq 1.0$, guard; $1.0<\mathrm{P} \leq 2.0$, low pollution; $2.0<\mathrm{P} \leq 3.0$, moderate pollution; and $3.0<\mathrm{P}$, severe pollution.

\subsection{Statistical analysis}

The data were analyzed using PASW software (PASW Version 18.0, SPSS Inc., Chicago, IL, USA). The statistical analysis included the K-S test, ANOVA, factor analysis, cluster analysis, multiple comparisons and correlation methods. The fitted curve characterizing the relationship between the heavy metal content and the distance from the roadside, and the box plot presenting the soil pollution status of different heavy metals at the four different sites, was analyzed using Origin 9.0 software (OriginLab Corp., Northampton, USA).

\section{Results and discussion}

\subsection{Content of heavy metals in soils}

Table 2 summarizes the contents of heavy metals in roadside soils at the four different sites. The mean values are presented differently depending on the distribution pattern of the contents of the heavy metals, e.g., the arithmetic mean for a normal distribution, the median for a non-normal distribution and the geometric mean for a log-normal distribution as a result of its advantages in reflecting the average contents of these heavy metals in soils (Chen et al., 2001). The mean contents of the 11 heavy metals at site GM were lower than the corresponding background values (Qinghai background values), which were approved by the Chinese Ministry of Environmental Protection (CNEMC, 1990). At site TTH, the mean contents of V $(42.74 \mathrm{mg} / \mathrm{kg}$ ), Co (8.17 mg/kg), Ni (20.71 mg/kg), Cu (20.01 mg/kg), Rb (55.44 mg/kg) and $\mathrm{Tl}(0.480 \mathrm{mg} / \mathrm{kg})$ were lower than the corresponding background values, whereas the contents of $\mathrm{Zn}(132.71 \mathrm{mg} / \mathrm{kg})$, As ( $45.55 \mathrm{mg} / \mathrm{kg})$, $\mathrm{Cd}(0.342 \mathrm{mg} / \mathrm{kg})$ and $\mathrm{Pb}(32.63 \mathrm{mg} / \mathrm{kg})$ were higher than the background values (Qinghai background values). For the study areas in Tibet, the mean contents of $\mathrm{Cr}(265.29 \mathrm{mg} / \mathrm{kg}), \mathrm{Ni}(78.00 \mathrm{mg} / \mathrm{kg})$ and

Table 2

Descriptive statistics of heavy metal contents $(\mathrm{mg} / \mathrm{kg})$ in soils.

\begin{tabular}{|c|c|c|c|c|c|c|c|c|c|c|c|}
\hline & V & $\mathrm{Cr}$ & Co & $\mathrm{Ni}$ & $\mathrm{Cu}$ & $\mathrm{Zn}$ & As & $\mathrm{Cd}$ & $\mathrm{Rb}$ & $\mathrm{Pb}$ & $\mathrm{Tl}$ \\
\hline \multicolumn{12}{|c|}{$G M, n=33$, lithology $=$ sandy } \\
\hline DP & Normal & Log-normal & Normal & Normal & Normal & Normal & Normal & Normal & Normal & Normal & Normal \\
\hline Mean & $51.73^{\mathrm{a}}$ & $54.29^{\mathrm{a}}$ & $8.10^{\mathrm{a}}$ & $20.35^{\mathrm{a}}$ & $18.44^{\mathrm{a}}$ & $48.75^{\mathrm{a}}$ & $10.18^{a}$ & $0.126^{a}$ & $74.63^{\mathrm{a}}$ & $18.49^{\mathrm{a}}$ & $0.411^{\mathrm{a}}$ \\
\hline SD & 4.60 & 16.02 & 0.92 & 2.93 & 2.39 & 5.93 & 1.42 & 0.042 & 4.52 & 2.81 & 0.037 \\
\hline Min. & 42.38 & 40.14 & 5.43 & 16.34 & 15.23 & 39.39 & 9.31 & 0.086 & 61.20 & 14.86 & 0.177 \\
\hline Max. & 62.22 & 93.83 & 10.10 & 33.99 & 23.67 & 63.40 & 13.69 & 0.271 & 81.70 & 29.65 & 0.345 \\
\hline \multirow[t]{2}{*}{ CV (\%) } & 8.89 & 29.51 & 11.36 & 14.40 & 12.96 & 12.16 & 13.95 & 33.33 & 6.06 & 15.20 & 9.00 \\
\hline & $\mathrm{V}$ & $\mathrm{Cr}$ & Co & $\mathrm{Ni}$ & $\mathrm{Cu}$ & $\mathrm{Zn}$ & As & $\mathrm{Cd}$ & $\mathrm{Rb}$ & $\mathrm{Pb}$ & $\mathrm{Tl}$ \\
\hline \multicolumn{12}{|c|}{ TTH, $n=48$, lithology = sandy loam } \\
\hline DP & Normal & Log-normal & Normal & Normal & Normal & Log-normal & Normal & Normal & Normal & Normal & Normal \\
\hline Mean & $42.74^{\mathrm{b}}$ & $71.55^{\mathrm{b}}$ & $8.17^{\mathrm{a}}$ & $20.71^{\mathrm{a}}$ & $20.01^{\mathrm{a}, \mathrm{b}}$ & $132.71^{\mathrm{b}}$ & $45.55^{\mathrm{b}}$ & $0.342^{\mathrm{b}}$ & $55.44^{\mathrm{b}}$ & $32.63^{b}$ & $0.480^{\mathrm{b}}$ \\
\hline SD & 5.57 & 52.46 & 2.36 & 3.29 & 6.05 & 90.83 & 14.26 & 0.161 & 7.41 & 7.89 & 0.093 \\
\hline Min. & 32.76 & 34.68 & 4.94 & 15.12 & 12.42 & 53.67 & 23.68 & 0.144 & 42.79 & 19.74 & 0.340 \\
\hline Max. & 59.68 & 289.70 & 17.84 & 33.68 & 34.18 & 364.15 & 69.86 & 0.891 & 80.42 & 51.67 & 0.684 \\
\hline \multirow[t]{2}{*}{ CV $(\%)$} & 13.03 & 73.32 & 28.89 & 15.89 & 30.23 & 68.44 & 31.31 & 47.08 & 13.37 & 24.18 & 19.38 \\
\hline & $\mathrm{V}$ & $\mathrm{Cr}$ & Co & $\mathrm{Ni}$ & $\mathrm{Cu}$ & $\mathrm{Zn}$ & As & $\mathrm{Cd}$ & $\mathrm{Rb}$ & $\mathrm{Pb}$ & $\mathrm{Tl}$ \\
\hline \multicolumn{12}{|c|}{$N Q, n=48$, lithology $=$ clay } \\
\hline DP & Normal & Normal & Normal & Normal & Normal & Normal & Normal & Non-normal & Normal & Non-normal & Normal \\
\hline Mean & $68.29^{c}$ & $265.29^{c}$ & $12.11^{\mathrm{b}}$ & $78.00^{\mathrm{b}}$ & $18.32^{\mathrm{a}}$ & $60.31^{c}$ & $18.28^{c}$ & $0.114^{\mathrm{a}}$ & $115.48^{\mathrm{c}}$ & $26.82^{\mathrm{c}}$ & $0.606^{\mathrm{c}}$ \\
\hline SD & 6.89 & 93.85 & 0.97 & 10.48 & 1.52 & 5.76 & 2.84 & 0.071 & 11.74 & 4.77 & 0.063 \\
\hline Min. & 53.44 & 122.22 & 9.67 & 49.48 & 14.77 & 48.97 & 13.08 & 0.083 & 93.36 & 23.93 & 0.485 \\
\hline Max. & 81.07 & 564.20 & 13.97 & 102.84 & 24.20 & 75.93 & 23.67 & 0.439 & 169.65 & 43.52 & 0.889 \\
\hline \multirow[t]{2}{*}{$\mathrm{CV}(\%)$} & 10.09 & 35.38 & 8.01 & 13.44 & 8.30 & 9.55 & 15.54 & 62.28 & 10.17 & 17.79 & 10.40 \\
\hline & $\mathrm{V}$ & $\mathrm{Cr}$ & Co & $\mathrm{Ni}$ & $\mathrm{Cu}$ & $\mathrm{Zn}$ & As & $\mathrm{Cd}$ & $\mathrm{Rb}$ & $\mathrm{Pb}$ & $\mathrm{Tl}$ \\
\hline \multicolumn{12}{|c|}{$D X, n=39$, lithology $=$ clay } \\
\hline DP & Normal & Normal & Normal & Normal & Normal & Log-normal & Normal & Normal & Normal & Non-normal & Normal \\
\hline Mean & $71.02^{c}$ & $67.93^{\mathrm{b}}$ & $9.99^{c}$ & $26.92^{\mathrm{c}}$ & $20.74^{\mathrm{b}}$ & $68.25^{d}$ & $17.64^{\mathrm{c}}$ & $0.145^{\mathrm{a}}$ & $140.32^{\mathrm{d}}$ & $33.13^{d}$ & $0.763^{d}$ \\
\hline SD & 2.61 & 8.91 & 0.44 & 3.42 & 3.13 & 8.30 & 1.35 & 0.064 & 4.61 & 14.21 & 0.036 \\
\hline Min. & 62.22 & 57.71 & 8.60 & 22.02 & 17.14 & 56.48 & 13.97 & 0.075 & 124.18 & 27.43 & 0.678 \\
\hline Max. & 74.79 & 98.00 & 10.96 & 42.93 & 29.72 & 93.60 & 20.13 & 0.318 & 148.13 & 83.44 & 0.838 \\
\hline CV (\%) & 3.68 & 13.12 & 4.40 & 12.70 & 15.09 & 12.16 & 7.65 & 44.14 & 3.29 & 42.89 & 11.34 \\
\hline $\operatorname{ACV}(\%)^{\mathrm{a}}$ & 8.92 & 37.83 & 13.42 & 14.11 & 16.65 & 25.58 & 17.11 & 46.71 & 8.68 & 25.02 & 16.37 \\
\hline Qinghai BV ${ }^{\mathrm{b}}$ & 71.8 & $70.1(66.3)$ & 10.1 & 29.6 & 22.2 & $80.3(76.1)$ & 14.0 & 0.137 & 102.00 & 20.9 & 0.588 \\
\hline Tibet BV ${ }^{\mathrm{c}}$ & 76.60 & 76.60 & 11.8 & 32.1 & 21.9 & $74.0(71.1)$ & 19.7 & $0.081(0.074)$ & 139.00 & $29.1(27.9)$ & 0.697 \\
\hline China BV ${ }^{d}$ & 82.4 & $61.0(53.9)$ & 12.7 & 26.9 & 22.6 & $74.2(67.7)$ & 11.2 & $0.097(0.079)$ & 111 & $26.0(23.5)$ & 0.620 \\
\hline
\end{tabular}

$\mathrm{ACV}=$ average coefficient of variation; $\mathrm{CV}=$ coefficient of variation; $\mathrm{DP}=$ distribution pattern.

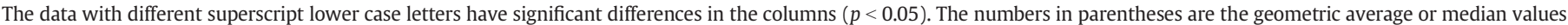
according to the distribution patterns of the heavy metal contents in the column.

a ACV (\%) is the average CV (\%) of the four sampling sites.

b Qinghai background value applied for Golmud (GM) and Tuotuohe (TTH) (CNEMC, 1990).

c Tibet background value applied for Nagqu (NQ) and Damxung (DX) (CNEMC, 1990).

d Chinese background value applied for GM, TTH, NQ, and DX (CNEMC, 1990). 
$\mathrm{Cd}(0.114 \mathrm{mg} / \mathrm{kg})$ at site NQ and the mean contents of Cd $(0.145 \mathrm{mg} / \mathrm{kg})$, $\mathrm{Rb}(140.32 \mathrm{mg} / \mathrm{kg}), \mathrm{Pb}(33.13 \mathrm{mg} / \mathrm{kg})$ and $\mathrm{Tl}(0.763 \mathrm{mg} / \mathrm{kg})$ at site DX were higher than the corresponding background values. Some heavy metals, such as $\mathrm{Cr}, \mathrm{Zn}, \mathrm{As}, \mathrm{Cd}, \mathrm{Rb}, \mathrm{Pb}$ and $\mathrm{Tl}$, at one of the sites had higher contents than the background values for China, possibly partly due to the high natural contents of the elements and the high levels of As in the soils of the Tibetan Plateau, as reported previously by Zhang et al. (2002) and Sheng et al. (2012).

The percentage coefficients of variation for $\mathrm{Cr}, \mathrm{Cu}, \mathrm{Zn}, \mathrm{As}, \mathrm{Cd}$ and $\mathrm{Pb}$ at some sites along the Qinghai-Tibet highway were higher than those of the other heavy metals. These included: $\mathrm{Cr}(29.51 \%)$ and Cd (33.33\%) at site GM; $\mathrm{Cr}$ (73.32\%), $\mathrm{Zn}(68.44 \%)$ and $\mathrm{Cd}(47.08 \%)$ at site TTH; $\mathrm{Cr}$ (35.38\%), As (15.54\%), Cd (62.28\%) and $\mathrm{Pb}(17.79 \%)$ at site NQ; and $\mathrm{Cu}(15.09 \%), \mathrm{Cd}(44.14 \%)$ and $\mathrm{Pb}(42.89 \%)$ at site DX (Table 2). The percentage coefficients of variation of the same heavy metal varied between sampling sites. To remove these regional differences, the average coefficients of variation (ACVs) were also calculated (Table 2). The results showed that the ACVs followed the sequence $\mathrm{Cd}(46.71 \%)>\mathrm{Cr}(37.83 \%)>\mathrm{Zn}(25.58 \%)>\mathrm{Pb}(25.02 \%)>\mathrm{As}$ $(17.11 \%)>\mathrm{Cu}(16.65 \%)>\mathrm{Tl}(16.37 \%)>\mathrm{Ni}(14.11 \%)>\mathrm{Co}(13.42 \%)>\mathrm{V}$ $(8.92 \%)>\mathrm{Rb}(8.68 \%)$. The percentage coefficients of variation reflect the dispersion and variance of the data. The higher the percentage coefficient of variation, the more abnormally the data behave (Lu, 2010). These results indicated that the contents of $\mathrm{Cd}, \mathrm{Cr}, \mathrm{Zn}, \mathrm{Pb}, \mathrm{As}$ and $\mathrm{Cu}$ had considerable variability in the soils along the Qinghai-Tibet highway. Many studies have reported that the contents of these heavy metals in roadside soils are significantly related to traffic (Chen et al., 2010; Wang et al., 2013). We therefore speculated that the contents of $\mathrm{Cd}, \mathrm{Cr}, \mathrm{Zn}, \mathrm{Pb}, \mathrm{As}$ and $\mathrm{Cu}$ in the soils were related to anthropogenic activities along the Qinghai-Tibet highway, but this needed further verification.

The results of the ANOVA analysis presented in Table 2 show that the contents of $\mathrm{Zn}, \mathrm{Rb}, \mathrm{Pb}$ and $\mathrm{Tl}$ were significantly different $(p<0.05)$ in different environments along the Qinghai-Tibet highway. The contents of some heavy metals were similar in different environments ( $\mathrm{V}$ and $\mathrm{As}$ at sites NQ and DX; Cr at sites TTH and DX; Co and Ni at sites GM and TTH; $\mathrm{Cu}$ at sites GM, TTH and NQ; and Cd at sites GM, NQ and DX).

\subsection{Interrelationships among heavy metals in soils along the Qinghai-Tibet} highway

The contents of heavy metals in soils are a result of geological and anthropogenic inputs (Zaharescu et al., 2009). To distinguish the different origins of the heavy metals in soils along the Qinghai-Tibet highway, factor analysis was performed to investigate the relationships among the 11 heavy metals determined in these soil samples. Factors with an eigenvalue $>1$ were extracted with an orthogonal varimax rotation used for rotating the axes for a better fit through the variable cluster (Lu, 2010). A total of three factors were extracted, accounting for $87.65 \%$ of the total variance (Table 3). Factor 1, accounting for $33.67 \%$ of the variance, positively corresponded to $\mathrm{Cu}, \mathrm{Zn}, \mathrm{As}, \mathrm{Cd}$ and $\mathrm{Pb}$. Three heavy metals $(\mathrm{V}, \mathrm{Rb}$ and $\mathrm{Tl})$ were positively related to factor $2(30.83 \%)$ and the remaining heavy metals $(\mathrm{Cr}, \mathrm{Co}$ and $\mathrm{Ni})$ were positively related to factor 3 (23.15\%). Fig. 2 presents the interrelationships among the contents of heavy metals in the soils along the Qinghai-Tibet highway.

Cluster analysis was also performed on the contents of the 11 heavy metals determined in roadside soils and this further verified the results obtained through factor analysis. The results are presented as a hierarchical dendrogram and heavy metals in the same group are expected to be from a common anthropogenic or natural source (Khan et al., 2011). Three distinct groups can be identified in Fig. 2: the first group consisted of $\mathrm{Cu}, \mathrm{Zn}, \mathrm{As}, \mathrm{Cd}$ and $\mathrm{Pb}$; the second group consisted of $\mathrm{V}, \mathrm{Rb}$ and $\mathrm{Tl}$; and the third group consisted of $\mathrm{Cr}, \mathrm{Co}$ and $\mathrm{Ni}$. A lower distance criterion indicates a closer association (Lee et al., 2006). Clustering of the heavy metals occurred at a high distance criterion between 10 and 15 , possibly due to environmental heterogeneity. As a whole, the grouping of heavy metals based on cluster analysis was consistent with the results from factor analysis.

Many previously published reports have shown that $\mathrm{Cu}, \mathrm{Zn}, \mathrm{As}, \mathrm{Cd}$ and $\mathrm{Pb}$ are indicator heavy metals in contaminated soils near highways (Chen et al., 2010; Wang et al., 2012; Yan et al., 2013; Werkenthin et al., 2014). Therefore it was speculated that $\mathrm{Cu}, \mathrm{Zn}, \mathrm{As}, \mathrm{Cd}$ and $\mathrm{Pb}$ (related to factor 1) were derived from a similar source and might be related to anthropogenic inputs.

\subsection{Relationship between heavy-metal contents in roadside soils and distance from the highway}

The factor 1 scores (corresponding to $\mathrm{Cu}, \mathrm{Zn}, \mathrm{As}, \mathrm{Cd}$ and $\mathrm{Pb}$ ) had significantly negative correlations with distance perpendicular to the highway, whereas the other two factors were not statistically significant (Table 4). The soil contents of $\mathrm{Cu}, \mathrm{Zn}, \mathrm{Cd}$ and $\mathrm{Pb}$ were among the five heavy metals significantly correlated with the distance from the highway $(p<0.01)$, indicating that the contents of these heavy metals in the topsoil along the Qinghai-Tibet highway were higher in samples taken nearer the road. Some studies have shown that the contents of traffic-related metals in topsoil decrease with increasing distance from the road edge (Liu et al., 2009; Yan et al., 2013; Werkenthin et al., 2014). These results support the suggestion that the contents of $\mathrm{Cu}, \mathrm{Zn}, \mathrm{As}, \mathrm{Cd}$ and $\mathrm{Pb}$ in soils were closely related to traffic.

Zhang et al. (2012) proposed that three criteria should be considered when trying to identify traffic-related metals: (1) relatively high percentage coefficients of variation; (2) multivariate relationships different from those of heavy metals from natural origins; and (3) a significantly negative relationship between the content of the heavy metals in the soil and the distance to the road edge. The results of the descriptive statistics, cluster analysis and factor analysis, and the correlation analysis agreed well with each other and followed these three criteria. Therefore, we concluded that $\mathrm{Cu}, \mathrm{Zn}, \mathrm{As}, \mathrm{Cd}$ and $\mathrm{Pb}$ were traffic-related metals and were mainly derived from road transportation. Although $\mathrm{Cr}$ did not have the same multivariate relationships as $\mathrm{Cu}, \mathrm{Zn}, \mathrm{As}, \mathrm{Cd}$ and $\mathrm{Pb}$ based on cluster analysis and factor analysis, its high percentage coefficient of variation and significantly negative relationship with distance from the road were similar to those of the traffic-related metals. In addition, soil $\mathrm{Cr}$ (predominantly originating from oil residues and the abrasion of brake pads and tires) has also been identified as an indicator of pollution resulting from traffic (Zehetner et al., 2009). Therefore soil $\mathrm{Cr}$ was also classified as a traffic-related metal along the Qinghai-Tibet highway. It was found that these traffic-related metals included a larger number of different elements than the soils along the Qinghai-Tibet railway in our earlier study, which only contained $\mathrm{Cd}, \mathrm{Zn}$ and $\mathrm{Pb}$ (Zhang et al., 2012).

Table 3

Rotated component matrix of factor analysis showing interrelationship among heavy metals.

\begin{tabular}{|c|c|c|c|c|c|c|c|c|c|c|c|c|c|}
\hline Elements & V & $\mathrm{Cr}$ & Co & $\mathrm{Ni}$ & $\mathrm{Cu}$ & $\mathrm{Zn}$ & As & $\mathrm{Cd}$ & $\mathrm{Rb}$ & $\mathrm{Pb}$ & $\mathrm{Tl}$ & Eigenvalue & $\%$ of variance \\
\hline $\mathrm{F} 1$ & -0.321 & 0.032 & 0.064 & -0.188 & 0.756 & 0.939 & 0.856 & 0.932 & -0.326 & 0.617 & 0.134 & 3.703 & 33.67 \\
\hline $\mathrm{F} 2$ & 0.861 & 0.008 & 0.568 & 0.186 & 0.358 & -0.150 & -0.253 & -0.267 & 0.913 & 0.539 & 0.939 & 3.391 & 30.83 \\
\hline F3 & 0.341 & 0.952 & 0.751 & 0.950 & -0.020 & -0.043 & -0.072 & -0.008 & 0.198 & -0.056 & 0.087 & 2.546 & 23.15 \\
\hline
\end{tabular}

F-factor. 

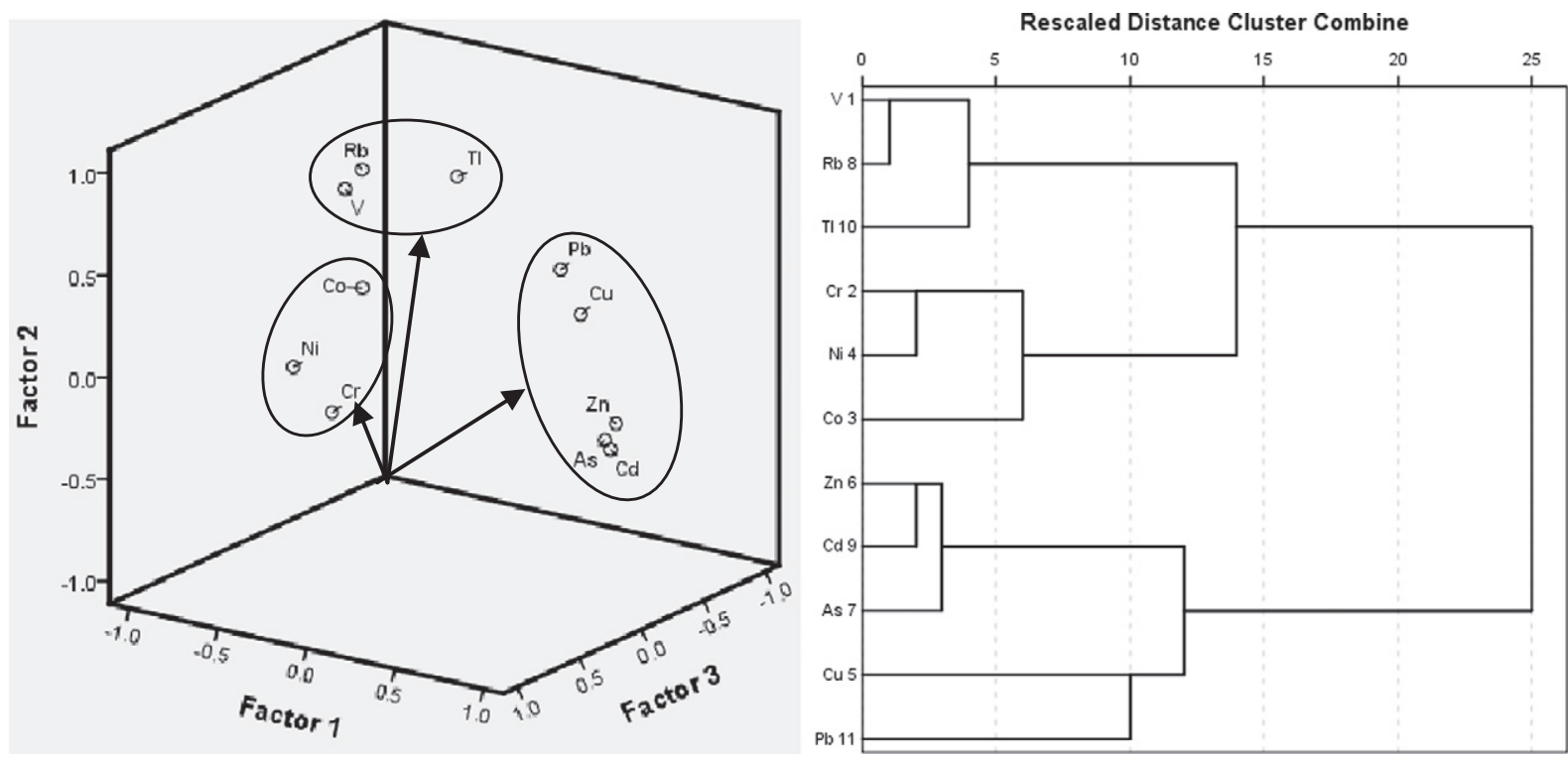

Fig. 2. Scatter plots and cluster tree of elements showing interrelationships among the heavy metals.

\subsection{Regression models and background values of traffic-related metals}

Further analysis based on the four different natural environments along the Qinghai-Tibet highway showed that the contents of Cd and $\mathrm{Pb}$ at all four sites were significantly negatively correlated with the distance from the road edge, whereas the contents of other traffic-related metals at the different sites showed more varied relationships (Table 4). Similar relationships are also shown in Fig. 3. There were three different distribution patterns of the traffic-related metals in soils and most of the contents decreased exponentially with increasing distance from the road edge. It was noted that some heavy metals at some of the sites (e.g., Cu at site GM and As at sites GM, NQ and DX) showed an exponential increase with increasing distance from the road edge, whereas $\mathrm{Cu}$ at site NQ and Zn at sites GM and NQ fluctuated with increasing distance from the road edge.

Wheeler and Rolfe (1970) found that total content of heavy metals in roadside soils decreased at more than double an exponential rate as the distance from the roadside increased. Leonzio and Pisani (1987) concluded that the distribution patterns of traffic-related metals followed a first-order kinetics equation and that the coefficient of decrease was -0.034 . Other workers have reported that the contents of all heavy metal contaminants in soils decreased exponentially with increasing distance from the roadside (Blok, 2005; Nabulo et al., 2006; Guo et al., 2007, 2008; Yan et al., 2013). In our study, most of the distribution patterns (about 80.83\%) showed similar characteristics and conformed to a first-order kinetics equation. Anthropogenic activities, such as industrialization, agricultural cultivation and fossil fuel

Table 4

Correlation coefficients for the factors and their related heavy metal contents $(\mathrm{mg} / \mathrm{kg}$ ) with distances from the roadside.

\begin{tabular}{llrlrr}
\hline & Whole & GM & TTH & NQ & \multicolumn{1}{l}{ DX } \\
\hline Factor 1 & $-0.271^{* *}$ & & & & \\
Cu & $-0.323^{* *}$ & $0.684^{* *}$ & $-0.573^{* *}$ & -0.045 & $-0.558^{* *}$ \\
Zn & $-0.216^{* *}$ & $-0.071^{* *}$ & $-0.821^{* *}$ & 0.252 & $-0.515^{* *}$ \\
As & -0.065 & $0.693^{* *}$ & $-0.651^{* *}$ & $0.528^{* *}$ & $0.476^{* *}$ \\
Cd & $-0.462^{* *}$ & $-0.640^{* *}$ & $-0.595^{* *}$ & $-0.594^{* *}$ & $-0.584^{* *}$ \\
Pb & $-0.348^{* *}$ & $-0.407^{* *}$ & $-0.586^{* *}$ & $-0.565^{* *}$ & $-0.873^{* *}$ \\
Cr & $-0.267^{* *}$ & $-0.343^{* *}$ & $-0.707^{* *}$ & $-0.460^{* *}$ & $-0.454^{* *}$ \\
Factor 2 & 0.060 & & & & \\
Factor 3 & -0.064 & & & & \\
\hline
\end{tabular}

* Correlation is significant at the 0.05 level (two-tailed).

** Correlation is significant at the 0.01 level (two-tailed). combustion, are very limited in the Tibetan Plateau (Cong et al., 2011) and along the Qinghai-Tibet highway (Yan et al., 2013). Therefore, the distribution patterns of the traffic-related metals in our study reflected their true diffusion characteristics and were similar to the pattern reported by Leonzio and Pisani (1987). The only difference from that study was the coefficient of decrease, which varied with the different heavy metals and landscapes rather than maintaining a constant value (Fig. 3). No other study has reported an exponential increase in heavy-metal contents in roadside soils with increasing distance from a highway ( $\mathrm{Cu}$ at site GM; As at sites GM, NQ and DX).

Most of the plant species in the area close to the Qinghai-Tibet highway were dicotyledonous weeds resulting from the frequent road works. These are very different from the plants found in areas further away from the highway (Ma et al., 2004). These roadside weeds probably accumulate specific heavy metals by extracting them from the soil (Galal and Shehata, 2015). This process of phytoextraction may decrease the content of these specific heavy metals in roadside soils and may eventually affect their distribution pattern in soils. This proposal should be interpreted with caution and will require verification during future follow-up studies.

The affected distance, i.e., the distance at which the contents of traffic-related metals become constant, also varied between the different heavy metals and the different landscapes, ranging from 20 to $250 \mathrm{~m}$ (Table 5). This distance was greater than that along the Qinghai-Tibet railway (20 m) (Zhang et al., 2012) and has also been reported by Yan et al. (2013). It was found that the traffic-related metals in soils within the affected distance were easily extracted by the dominant plant species, such as Stipa purpurea and Kobresia pygmaea, which were sources of food for both livestock and wildlife (Fu et al., 2013). These plant species may therefore pose a potential risk to the animals feeding on them (Zhang, 2013). Therefore a safe distance from the roadside should be set along the Qinghai-Tibet highway by local governments to reduce the potential risk to both livestock and wildlife from heavy metal contamination.

The background contents of some of the traffic-related metals at some sites were clearly higher than the background contents for Qinghai or Tibet - such as Cr at site NQ (219.37 mg/kg vs. $76.60 \mathrm{mg} / \mathrm{kg}$ ), As at site TTH $(32.82 \mathrm{mg} / \mathrm{kg}$ vs. $14.00 \mathrm{mg} / \mathrm{kg})$ and Cd at site TTH $(0.192 \mathrm{mg} / \mathrm{kg}$ vs. $0.137 \mathrm{mg} / \mathrm{kg}$ ) - and were also higher than the background values for China. It was noted that the background values for As at sites NQ and DX (20.47 mg/kg and $18.45 \mathrm{mg} / \mathrm{kg}$ ) were not very different from that for Tibet $(19.70 \mathrm{mg} / \mathrm{kg}$ ), but were higher than that for 

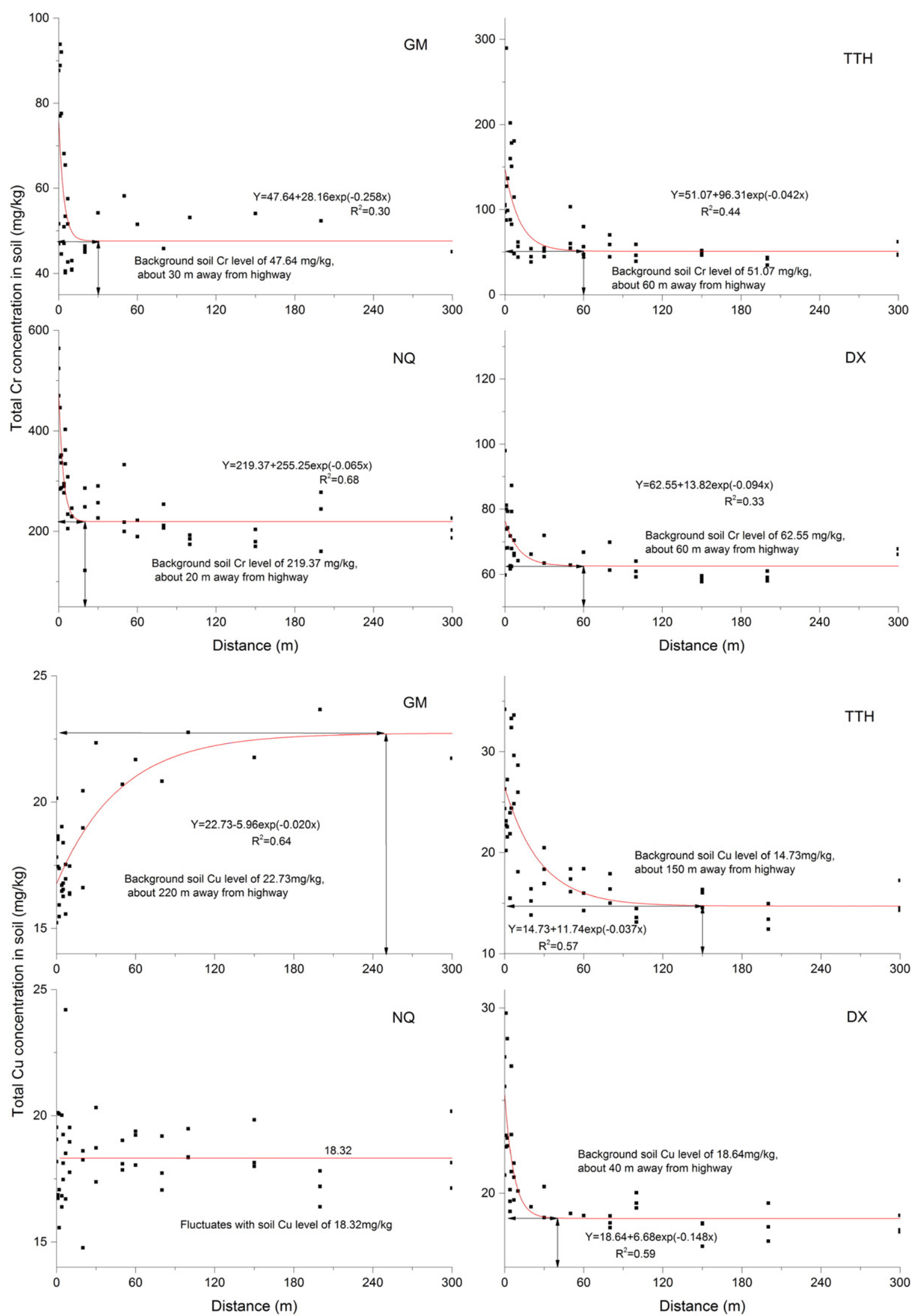

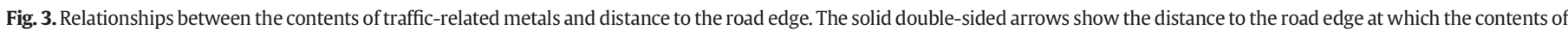
traffic-related metals became constant, representing the background concentrations of the heavy metals in the soil in the different environments. 

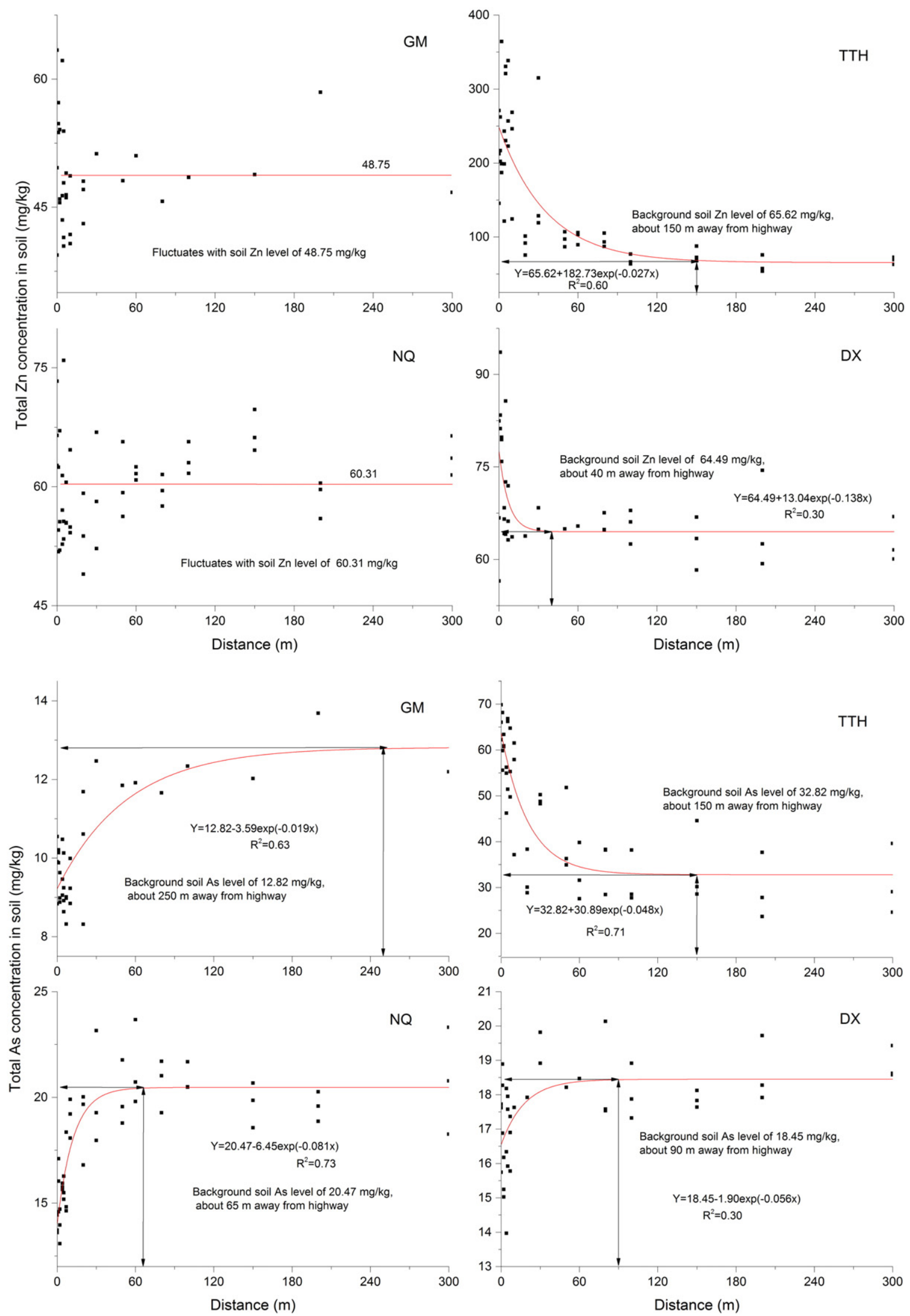

Fig. 3 (continued). 

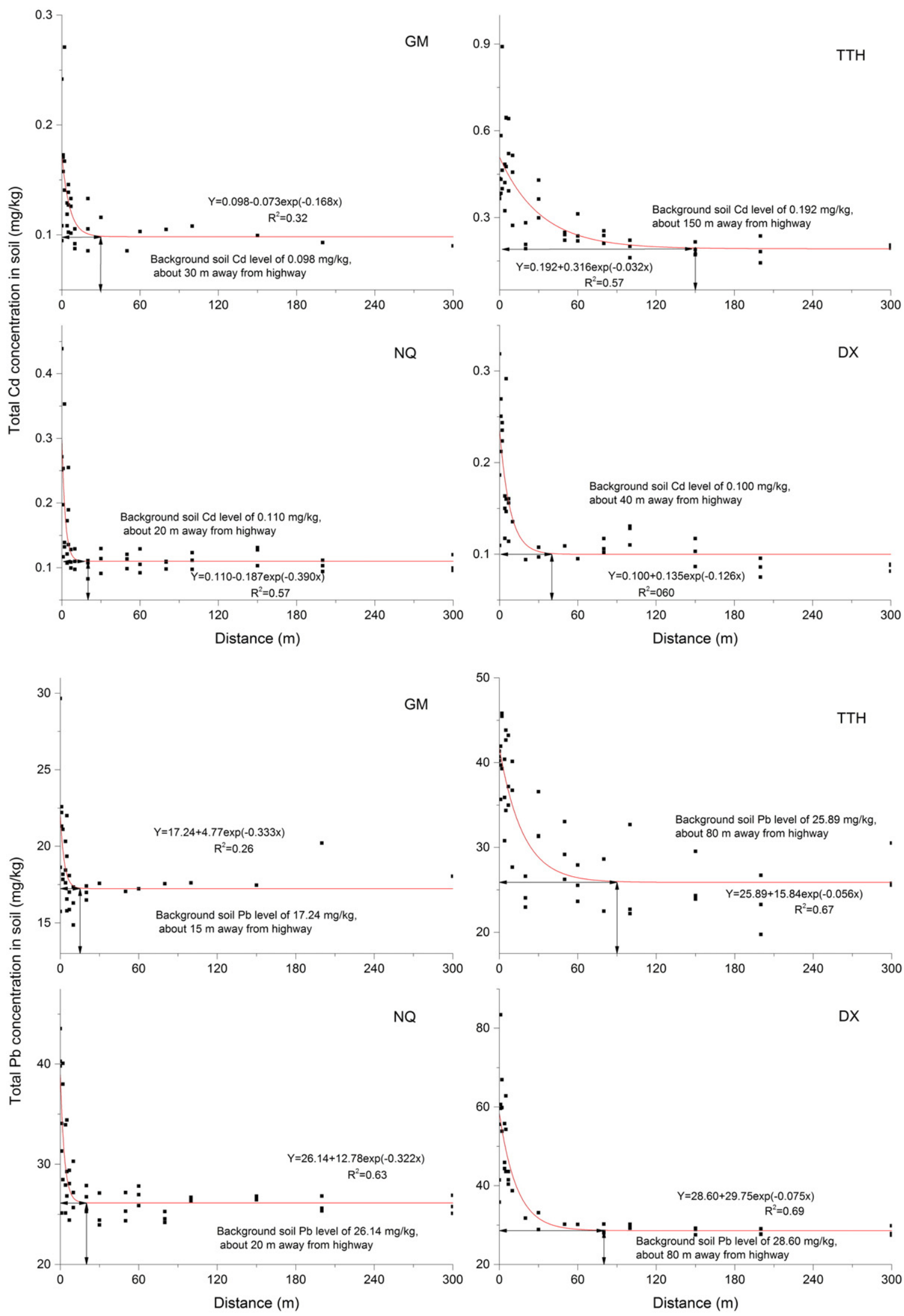

Fig. 3 (continued). 
Table 5

Background values of the traffic-related metals and the distances at which these values become constant.

\begin{tabular}{|c|c|c|c|c|c|c|c|c|c|c|c|c|}
\hline & \multicolumn{2}{|l|}{$\mathrm{Cr}$} & \multicolumn{2}{|l|}{$\mathrm{Cu}$} & \multicolumn{2}{|l|}{$\mathrm{Zn}$} & \multicolumn{2}{|l|}{ As } & \multicolumn{2}{|l|}{$\mathrm{Cd}$} & \multicolumn{2}{|l|}{$\mathrm{Pb}$} \\
\hline & $\begin{array}{l}\text { BV } \\
(\mathrm{mg} / \mathrm{kg})\end{array}$ & $\begin{array}{l}\text { Distance } \\
(\mathrm{m})\end{array}$ & $\begin{array}{l}\text { BV } \\
(\mathrm{mg} / \mathrm{kg})\end{array}$ & $\begin{array}{l}\text { Distance } \\
(\mathrm{m})\end{array}$ & $\begin{array}{l}\text { BV } \\
(\mathrm{mg} / \mathrm{kg})\end{array}$ & $\begin{array}{l}\text { Distance } \\
(\mathrm{m})\end{array}$ & $\begin{array}{l}\text { BV } \\
(\mathrm{mg} / \mathrm{kg})\end{array}$ & $\begin{array}{l}\text { Distance } \\
(\mathrm{m})\end{array}$ & $\begin{array}{l}\text { BV } \\
(\mathrm{mg} / \mathrm{kg})\end{array}$ & $\begin{array}{l}\text { Distance } \\
(\mathrm{m})\end{array}$ & $\begin{array}{l}\text { BV } \\
(\mathrm{mg} / \mathrm{kg})\end{array}$ & $\begin{array}{l}\text { Distance } \\
(\mathrm{m})\end{array}$ \\
\hline GM & 47.64 & 30 & 22.73 & 220 & 48.75 & - & 12.82 & 250 & 0.098 & 30 & 17.24 & 15 \\
\hline TTH & 51.07 & 60 & 14.73 & 150 & 65.62 & 150 & 32.82 & 150 & 0.192 & 150 & 25.89 & 80 \\
\hline Qinghai BV & 66.30 & - & 22.20 & - & 80.30 & - & 14.00 & - & 0.137 & - & 20.90 & - \\
\hline NQ & 219.37 & 20 & 18.32 & - & 60.31 & - & 20.47 & 65 & 0.110 & 20 & 26.14 & 20 \\
\hline DX & 62.55 & 60 & 18.64 & 40 & 64.69 & 40 & 18.45 & 90 & 0.100 & 40 & 28.60 & 80 \\
\hline Tibet BV & 76.60 & - & 21.9 & - & 74.00 & - & 19.70 & - & 0.081 & - & 29.10 & - \\
\hline China BV & 61.00 & - & 22.6 & - & 74.20 & - & 11.20 & - & 0.097 & - & 26.00 & - \\
\hline
\end{tabular}

$\mathrm{BV}=$ background value.

China $(11.20 \mathrm{mg} / \mathrm{kg})$; this has also been found in other studies (Zhang et al., 2002; Sheng et al., 2012). With respect to the landscape, the background contents of the traffic-related metals in soils at site TTH were higher than those at Qinghai. The background contents of $\mathrm{Cd}$ in the soils along the Qinghai-Tibet highway were higher than those of the background values in both Qinghai and Tibet.

\subsection{Enrichment of the traffic-related metals in soils along the highway}

Fig. 4 and Table 6 show the CFs for the traffic-related metals at the four different sites. The CFs ranged from 0.56 at site NQ to 5.67 at site $\mathrm{TTH}$, indicating a range from no pollution to considerable pollution. The CFs for the traffic-related metals at site TTH were higher than those at the other three sites and a fraction of these had a CF $>3$. In terms of the traffic-related metals, the CFs for Cd at site GM, Zn at site $\mathrm{TTH}, \mathrm{Cr}$ at site $\mathrm{NQ}$ and $\mathrm{Cd}$ and $\mathrm{Pb}$ at site $\mathrm{DX}$ were higher than those of other heavy metals in the same environment. The average CFs of the traffic-related metals along the Qinghai-Tibet highway were corrected to remove any regional differences. The results showed that the average CFs followed the sequence $\mathrm{Cd}(1.46)>\mathrm{Zn}(1.41)>\mathrm{Cr}(1.30)>\mathrm{Pb}$
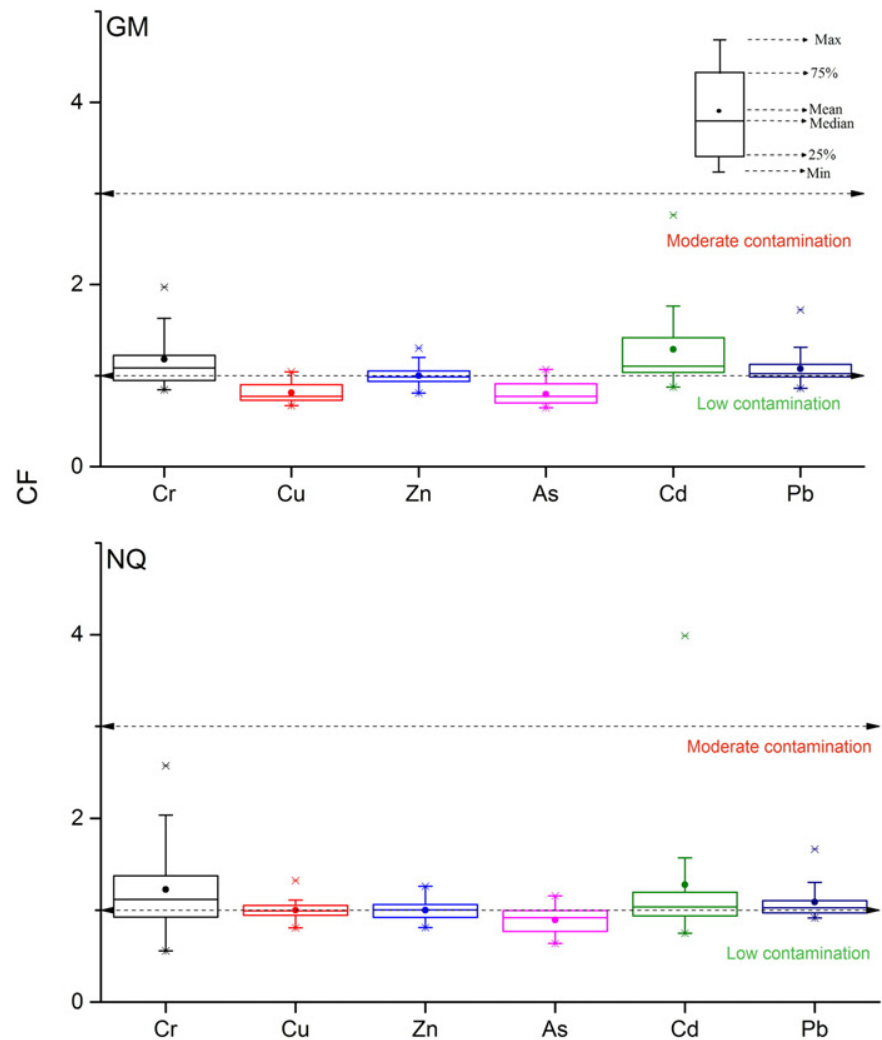

(1.20) $>\mathrm{Cu}(1.09)>\mathrm{As}$ (1.03). This shows that $\mathrm{Cd}$ made the largest contribution to pollution along the Qinghai-Tibet highway, whereas As made the smallest contribution (Table 6). Yan et al. (2013) also suggested that Cd originating from traffic activities made the largest contribution to pollution in soils along other highways in the Tibetan Plateau. This similarity in results may be because a portion of the highway section investigated by Yan et al. (2013) coincided with that of this study and had similar traffic characteristics.

Table 6 also shows the Nemero Synthesis Index (PN values) for the traffic-related metals at the four different sites. The index ranged from 0.80 to 4.49 , indicating a range from no pollution to severe pollution. However, only a small fraction of the sampling sites (about 8.33\%) had severe pollution. The order of the average $\mathrm{PN}$ values at the four different sites was TTH (2.10) > DX (1.37) $>\mathrm{NQ}(1.27)>\mathrm{GM}(1.20)$. The pollution levels at site TTH were moderate, whereas the levels of pollution at the other three sites were only light. These results indicate that the enrichment of traffic-related metals in most soils along the Qinghai-Tibet highway is light.

It is important to be able to characterize the relationships between the pollution indices for these heavy metals for use in policymaking to
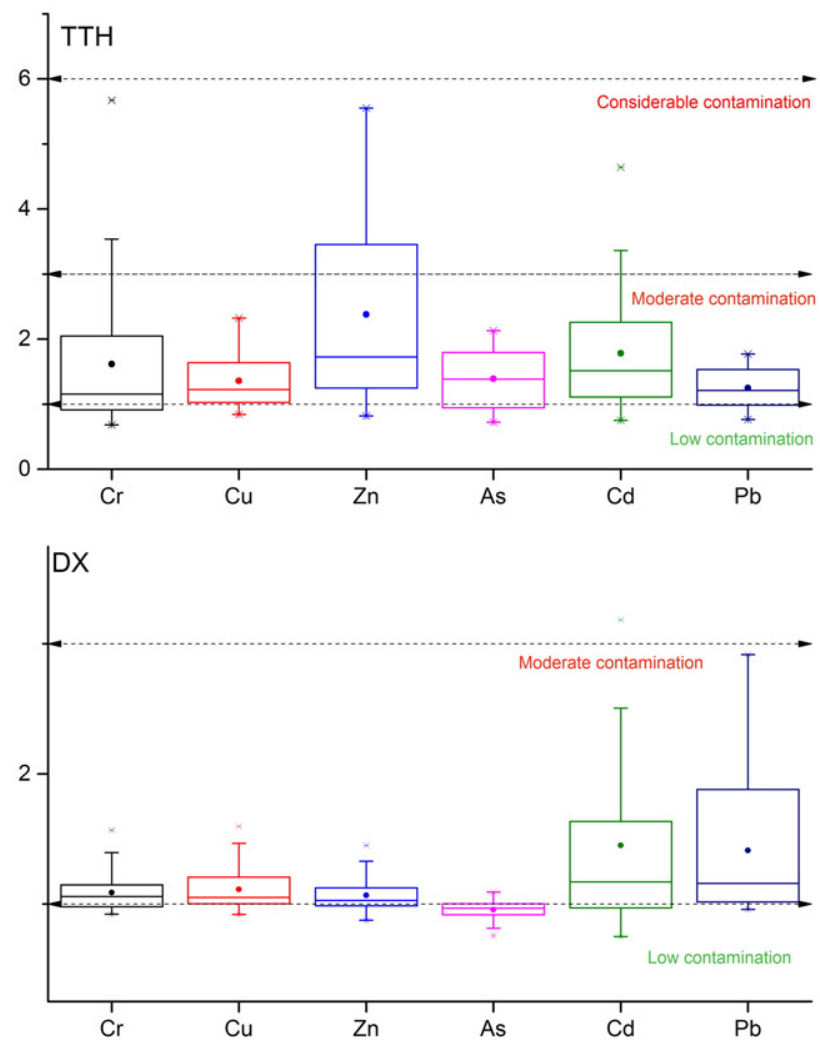

Fig. 4. Contamination factors (CFs) of the traffic-related metals in soils at the four sites along the Qinghai-Tibet highway. 
Table 6

CFs, PNs and multiple comparisons of different heavy metals from different sampling sites.

\begin{tabular}{|c|c|c|c|c|c|c|c|c|}
\hline & & $\mathrm{CF}(\mathrm{Cr})$ & $\mathrm{CF}(\mathrm{Cu})$ & $\mathrm{CF}(\mathrm{Zn})$ & $\mathrm{CF}(\mathrm{As})$ & $\mathrm{CF}(\mathrm{Cd})$ & $\mathrm{CF}(\mathrm{Pb})$ & PN \\
\hline \multirow[t]{3}{*}{ GM } & Mean \pm SD & $1.18 \pm 0.34^{\mathrm{Aab}}$ & $0.81 \pm 0.10^{\mathrm{Ac}}$ & $1.00 \pm 0.12^{\mathrm{Aa}}$ & $0.79 \pm 0.11^{\mathrm{Ac}}$ & $1.29 \pm 0.43^{\mathrm{Ab}}$ & $1.07 \pm 0.16^{\text {Aab }}$ & $1.20 \pm 0.30^{\mathrm{A}}$ \\
\hline & Max. & 1.97 & 1.04 & 1.30 & 1.07 & 2.76 & 1.72 & 2.12 \\
\hline & Min. & 0.84 & 0.67 & 0.81 & 0.65 & 0.87 & 0.86 & 0.90 \\
\hline \multirow[t]{3}{*}{ TTH } & Mean \pm SD & $1.62 \pm 1.03^{\mathrm{Bac}}$ & $1.36 \pm 0.41^{\mathrm{Ba}}$ & $2.38 \pm 1.38^{\mathrm{Bb}}$ & $1.39 \pm 0.43^{\mathrm{Bac}}$ & $1.78 \pm 0.84^{\mathrm{Bbc}}$ & $1.24 \pm 0.29^{\mathrm{Ba}}$ & $2.10 \pm 1.11^{\mathrm{B}}$ \\
\hline & Max. & 5.67 & 2.32 & 5.55 & 2.13 & 4.64 & 1.77 & 4.49 \\
\hline & Min. & 0.68 & 0.84 & 0.82 & 0.72 & 0.75 & 0.76 & 0.80 \\
\hline \multirow[t]{3}{*}{ NQ } & Mean \pm SD & $1.22 \pm 0.43^{\mathrm{Aa}}$ & $1.00 \pm 0.08^{\mathrm{Cb}}$ & $1.00 \pm 0.10^{\mathrm{Ab}}$ & $0.89 \pm 0.14^{\mathrm{Cc}}$ & $1.27 \pm 0.64^{\mathrm{Aa}}$ & $1.09 \pm 0.18^{\mathrm{Aab}}$ & $1.27 \pm 0.43^{\mathrm{A}}$ \\
\hline & Max. & 2.57 & 1.32 & 1.26 & 1.16 & 3.99 & 1.66 & 3.10 \\
\hline & Min. & 0.56 & 0.81 & 0.81 & 0.64 & 0.75 & 0.92 & 0.94 \\
\hline \multirow[t]{3}{*}{ DX } & Mean \pm SD & $1.03 \pm 0.28^{\text {Aab }}$ & $1.11 \pm 0.17^{\mathrm{Da}}$ & $1.06 \pm 0.13^{\mathrm{Aa}}$ & $0.96 \pm 0.07^{\mathrm{Db}}$ & $1.45 \pm 0.64^{\mathrm{ABC}}$ & $1.41 \pm 0.50^{\mathrm{Bc}}$ & $1.38 \pm 0.45^{A}$ \\
\hline & Max. & 1.57 & 1.59 & 1.45 & 1.09 & 3.19 & 2.92 & 2.56 \\
\hline & Min. & 0.92 & 0.92 & 0.87 & 0.76 & 0.75 & 0.96 & 0.94 \\
\hline Average & Mean \pm SD & $1.30 \pm 0.65^{\mathrm{ac}}$ & $1.09 \pm 0.31^{\mathrm{b}}$ & $1.41 \pm 0.96^{\mathrm{ac}}$ & $1.03 \pm 0.34^{\mathrm{b}}$ & $1.46 \pm 0.70^{\mathrm{a}}$ & $1.20 \pm 0.33^{c}$ & \\
\hline
\end{tabular}

The data with different superscript capital letters have significant differences in the columns and the data with superscript lower case letters have significant differences in columns.

protect crops near the roadside from pollution (Yan et al., 2013). As shown in Fig. 5, the PN values at the four different sites show an exponentially decreasing trend as the distance to the road edge increases, as also seen for the contents of the heavy metals. However, the affected distances at which the PN values became constant were different at the four different sites. The higher the value of the coefficient of decrease, the larger the distance from the roadside. The affected distance followed the sequence TTH $(150 \mathrm{~m})>\mathrm{DX}(50 \mathrm{~m})>\mathrm{GM}(20 \mathrm{~m})>\mathrm{NQ}(15 \mathrm{~m})$, which is slightly different from the average PN value. Yan et al. (2013) also verified this non-linear exponential relationship between the pollution index for the heavy metals (the ecological risk index) and the roadside distance; the coefficient of decrease $(0.133)$ calculated by Yan et al. (2013) was similar to that at site DX (0.114). However, the affected distance at which the PN values became constant at the different sites in this work were significantly different from the value of $40 \mathrm{~m}$ at which the RI values became constant in the study of Yan et al. (2013) possibly because the RI values were the average of five different road segments.

Irrespective of the CF and the PN value, or the affected distance of the heavy metals and the distribution patterns of the PN value, the four different sites behaved very differently. Site TTH showed the highest PN value (Table 6). Although transportation was the cause of the heavy metal pollution in soils along the Qinghai-Tibet highway, the results of the ANOVA analysis showed that the enrichment of heavy metals in the four sites behaved in a significantly different manner. The CFs of $\mathrm{Cr}, \mathrm{Cu}, \mathrm{Zn}, \mathrm{As}$ and $\mathrm{Cd}$ and the PN values had their highest average values at site $\mathrm{TTH}$, whereas the average $\mathrm{CF}$ of $\mathrm{Pb}$ at site DX was significantly higher than that at the other three sampling sites (Table 6). Previous

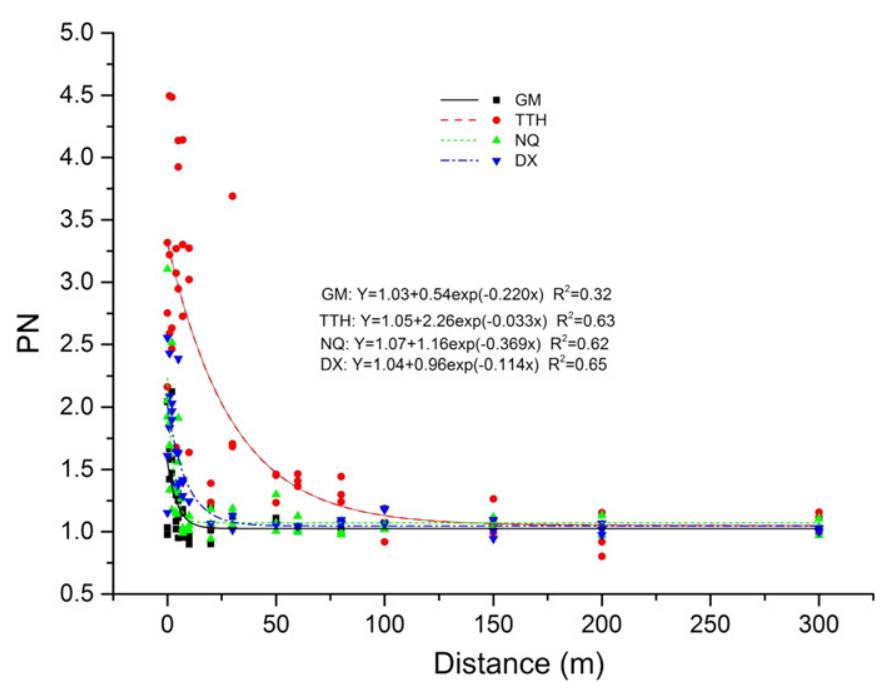

Fig. 5. Relationship between PN value and distance to the road edge. studies have verified that increased contents of traffic-related metals are significantly related to the volume of traffic and the speed of the vehicles (Blok, 2005; Nabulo et al., 2006; Chen et al., 2010). In this study, the changes in PN value were not in step with the flow of vehicles, which was almost the same at the four sampling sites. In addition, the PN value did not change significantly with the speed of the vehicles (Table 7) and therefore these traffic parameters did not play a key part in the differences in enrichment of traffic-related metals in soils along the Qinghai-Tibet highway.

Zhang et al. (2012) found that different terrains affected the degree of enrichment of heavy metals in soils. We found in this study that the height of the road bed was significantly related to the PN value (Table 7); it is possible that a high road bed contributes to a wider range of enrichment of traffic-related metals with the same kinetic energy. The wind speed can also account for differences in the PN value at different sampling sites (Table 7; Bakirdere and Yaman, 2008). The highest road bed and strongest winds at site TTH may therefore explain the greatest enrichment in traffic-related metals in roadside soils. The wind speeds at sites NQ and DX were almost the same, but the height of the roadbed at site DX was higher than that at site NQ, resulting in a greater enrichment of traffic-related metals at site DX. Although previous studies have found that other factors such as $\mathrm{pH}$, organic material, vegetation cover and precipitation can affect the enrichment of heavy metals in soils (Othman et al., 1997; Akbar et al., 2006; Hagler et al., 2012; Zhang et al., 2012), there was no significant relationship between these factors and the enrichment of traffic-related metals in roadside soils in this study (Table 7).

Some studies have found a high background level of As in the Tibetan Plateau (Zhang et al., 2002; Sheng et al., 2012) and this was also found in the soils at site TTH in this study (32.82 mg/kg). In addition to As, we also found high background levels of $\mathrm{Cr}$ at site NQ ( $219.37 \mathrm{mg} / \mathrm{kg}$ ). This background level of $\mathrm{Cr}$ at site NQ was twice that of the first criterion $(90 \mathrm{mg} / \mathrm{kg}$ ) and slightly lower than the second criterion $(250 \mathrm{mg} / \mathrm{kg}$ ) of the Chinese Environmental Quality Standard for Soils (CEPA, 1995); the first criterion is used to maintain natural background contents and the second criterion is the threshold value for protecting human health (Bai et al., 2011). Cd also had slightly higher background contents at site TTH. The background contents of other traffic-related metals at the four sites are lower than or close to the corresponding background levels (CEPA, 1995). The local government should therefore take account of the high background contents of heavy metals, especially $\mathrm{Cr}$ and As, in certain areas of the Tibetan Plateau. The roadside distance at which there is a potential risk to livestock and wildlife from the contamination of soils by heavy metals should be determined scientifically along the Qinghai-Tibet highway, especially in the area near site TTH.

The Qinghai-Tibet highway has a length of $1161 \mathrm{~km}$ and the four sites in this study may not be fully representative of the highway's overall environmental status. In addition, the results for the high 
Table 7

Pearson correlation coefficient of PN and environmental characteristics.

\begin{tabular}{|c|c|c|c|c|c|c|c|c|c|c|}
\hline & Coefficient of decrease & Latitude & $\mathrm{pH}$ & $\mathrm{OM}$ & AAP & AAT & AAWS & Vegetation cover & Height of road bed & Vehicle speed \\
\hline PN & 0.754 & 0.487 & 0.785 & -0.138 & 0.406 & -0.742 & $0.990^{* *}$ & -0.393 & $0.920^{*}$ & 0.468 \\
\hline
\end{tabular}

$\mathrm{OM}=$ organic material.

$*$ Correlation is significant at the 0.05 level (one-tailed).

** Correlation is significant at the 0.01 level (one-tailed).

background contents of some heavy metals should be interpreted with caution and require verification during future follow-up studies based on larger field investigations. However, the sites selected reflect the most typical landscapes along the Qinghai-Tibet highway and therefore these results are fairly representative of the current situation with respect to the contamination of roadside soils by heavy metals.

\section{Conclusion}

We determined the contents of 11 heavy metals ( $\mathrm{V}, \mathrm{Cr}, \mathrm{Co}, \mathrm{Ni}, \mathrm{Cu}, \mathrm{Zn}$, As, $\mathrm{Cd}, \mathrm{Rb}, \mathrm{Pb}$ and $\mathrm{Tl}$ ) in roadside soils in four different environments along the Qinghai-Tibet highway. $\mathrm{Cr}, \mathrm{Cu}, \mathrm{Zn}, \mathrm{As}, \mathrm{Cd}$ and $\mathrm{Pb}$ were identified as traffic-related metals through multivariate statistical analysis. The relationship between the contents of these traffic-related metals and the distance to the road edge showed three different distribution patterns: an exponential decline; exponential growth; and fluctuation around a fixed value. The CFs for the traffic-related metals ranged from no pollution to considerable pollution and the Nemero Synthesis Indexes of these heavy metals ranged from no pollution to severe pollution, suggesting a potential risk to wildlife and livestock. The enrichment level and roadside distance affected varied considerably between the four landscapes, with the highest contents of heavy metals at site TTH (alpine steppe), followed by sites DX and NQ (alpine meadow), with the lowest contents at site GM (alpine desert). Although transportation was the main cause of increased contents of the trafficrelated metals in roadside environments, regional differences (wind speed and terrain) had significant relationship with the enrichment level of these traffic-related metals in roadside soils. Cd made the largest contribution to the enrichment of soils along the Qinghai-Tibet highway. TTH was the key area for soil environment monitoring for its obvious heavy mental enrichment along the Qinghai-Tibet highway. The soils at one of the sites had high natural contents of As and $\mathrm{Cr}$, which should be of concern to both researchers and local governments.

\section{Acknowledgments}

The authors thank the three anonymous referees for their helpful comments on the manuscript. This study was supported by the Strategic Priority Research Program of the Chinese Academy of Sciences (Grant No. XDB03030500) and the National Natural Science Foundation of China (Grant Nos. 40801042 \& 90202012 ). The authors are grateful to Professor Yeqiao Wang and Lin Zhen of Jiangxi Normal University for their suggestions on the manuscript. In addition, the authors thank Dr Haibin Yu and Mr Wei Qi of Institute of Geographic Sciences and Natural Resource Research, CAS for their help during the field survey and material analysis.

\section{References}

Adachi, K., Tainosho, Y., 2004. Characterization of heavy metal particles embedded in tire dust. Environ. Int. 30 (8), 1009-1017.

Akbar, K.F., Hale, W.H.G., Headley, A.D., Athar, M., 2006. Heavy metal contamination of roadside soils of Northern England. Soil Water Res. 1 (4), 158-163.

Bai, J.H., Xiao, R., Cui, B.S., Zhang, K.J., Wang, Q.G., Liu, X.H., et al., 2011. Assessment of heavy metal pollution in wetland soils from the young and old reclaimed regions in the Pearl River Estuary, South China. Environ. Pollut. 159, 817-824.

Bakirdere, S., Yaman, M., 2008. Determination of lead, cadmium and copper in roadside soil and plants in Elazig, Turkey. Environ. Monit. Assess. 136 (1-3), 401-410.
Bashkin, V.N., 2003. Biogeochemical cycling of trace elements. In: Bashkin, V.N. (Ed.), Mordern Biogeochemistry. Kluwer Academic Publishers, Dordrecht, pp. 161-197.

Blok, J., 2005. Environmental exposure of road borders to zinc. Sci. Total Environ. 348 (1), 173-190.

Bozlaker, A., Spada, N.J., Fraser, M.P., Chellam, S., 2013. Elemental characterization of $\mathrm{PM}_{2.5}$ and $\mathrm{PM}_{10}$ Emitted from light duty vehicles in the Washburn Tunnel of Houston, Texas: release of rhodium, palladium, and platinum. Environ. Sci. Technol. 48 (1), 54-62.

CEPA, 1995. Environmental Quality Standard for Soils (GB 15618-1995). Chinese Environmental Protection Administration (Chinese).

Chen, M., Ma, L.Q., Hoogeweg, C.G., Harris, W.G., 2001. Arsenic background concentrations in Florida, USA surface soils: determination and interpretation. Environ. Forensics 2 (2), 117-126.

Chen, X., Xia, X.H., Zhao, Y., Zhang, P., 2010. Heavy metal contents in roadside soils and correlation with urban traffic in Beijing, China. J. Hazard. Mater. 181 (1), 640-646.

Chow, T.J., 1970. Lead accumulation in roadside soil and grass. Nature 225, 295-296.

CNEMC (China National Environmental Monitoring Center), 1990. The Backgrounds of Soil Environment in China. China Environmental Science Press, Beijing (Chinese).

Cong, Z.Y., Kang, S.C., Luo, C.L., Li, Q., Huang, J., Gao, S.P., 2011. Trace elements and lead isotopic composition of $\mathrm{PM}_{10}$ in Lhasa, Tibet. Atmos. Environ. 45 (34), 6210-6215.

Fu, J.J., Yi Xi, C.M., Chen, H., Miao, Y.J., Hu, T.M., Xu, Y.F., 2013. Responses of dominant plant nutrients to grazing intensity in Koberesia pygmaea meadow of the Qinghai-Tibet plateau. Pratacultural Sci. 30 (4), 560-565.

Galal, T.M., Shehata, H.S., 2015. Bioaccumulation and translocation of heavy metals by Plantago major L. grown in contaminated soils under the effect of traffic pollution. Ecol. Indic. 48, 244-251.

Guo, G.H., Chen, T.B., Song, B., Yang, J., Huang, Z.C., Lei, M., et al., 2007. Emissions of heavy metals from road traffic and effect of emitted lead on land contamination in China: a primary study. Geogr. Res. 26 (5), 922-930 (Chinese).

Guo, G.H., Lei, M., Chen, T.B., Song, B., Li, X.Y., 2008. Effect of road traffic on heavy metals in road dusts and roadside soils. Acta Sci. Circumst. 28 (10), 1937-1945 (Chinese).

Hagler, G.S.W., Lin, M.Y., Khlystov, A., Baldauf, R.W., Isakov, V., Faircloth, J., et al., 2012. Field investigation of roadside vegetative and structural barrier impact on near-road ultrafine particle contents under a variety of wind conditions. Sci. Total Environ. 419, 7-15.

Hakanson, L., 1980. An ecological risk index for aquatic pollution control. A sedimentological approach. Water Res. 14 (8), 975-1001.

Hjortenkrans, D.S.T., Bergbäck, B.G., Häggerud, A.V., 2007. Metal emissions from brake linings and tires: case studies of Stockholm, Sweden 1995/1998 and 2005. Environ. Sci. Technol. 41 (15), 5224-5230.

Khan, A.B., Kathi, S., 2014. Evaluation of heavy metal and total petroleum hydrocarbon contamination of roadside surface soil. Int. J. Eviron. Sci. Technol. 1-12.

Khan, M.N., Wasim, A.A., Sarwar, A., Rasheed, M.F., 2011. Assessment of heavy metal toxicants in the roadside soil along the N-5, National Highway, Pakistan. Environ. Monit. Assess. 182 (1-4), 587-595.

Klein, J.A., Harte, J., Zhao, X., 2004. Experimental warming causes large and rapid species loss, dampened by simulated grazing, on the Tibetan Plateau. Ecol. Lett. 7 (12), 1170-1179.

Krishna, A.K., Satyanarayanan, M., Govil, P.K., 2009. Assessment of heavy metal pollution in water using multivariate statistical techniques in an industrial area: a case study from Patancheru, Medak District, Andhra Pradesh, India. J. Hazard. Mater. 167 (1), 366-373.

Lee, C.S., Li, X., Shi, W., Cheung, S.C.N., Thornton, I., 2006. Metal contamination in urban, suburban, and country park soils of Hong Kong: a study based on GIS and multivariate statistics. Sci. Total Environ. 356 (1), 45-61.

Leonzio, C., Pisani, A., 1987. An evaluative model for lead distribution in roadside ecosystems. Chemosphere 16 (7), 1387-1394.

Li, X.P., Feng, L.N., 2010. Spatial distribution of hazardous elements in urban topsoils surrounding Xi'an industrial areas, (NW, China): controlling factors and contamination assessments. J. Hazard. Mater. 174 (1), 662-669.

Liu, H., Chen, L.P., Ai, Y.W., Yang, X., Yu, Y.H., Zuo, Y.B., et al., 2009. Heavy metal contamination in soil alongside mountain railway in Sichuan, China. Environ. Monit. Assess. $152,25-33$.

Loska, K., Wiechuła, D., Korus, I., 2004. Metal contamination of farming soils affected by industry. Environ. Int. 30 (2), 159-165.

Lu, W.D., 2010. SPSS Statistical Analysis. 4th ed. Publishing House of Electronics Industry, Beijing (Chinese).

Ma, S.Z., Chen, G.C., Peng, M., Zhou, G.Y., Zhao, Y.L., 2004. The alpine steppe vegetation restoration process of fountainhead region of Yangtze River. China Environ. Sci. 15 (5), 761-767.

Ma, J.H., Chu, C.J., Li, J., Song, B., 2009. Heavy metal pollution in soils on railroad side of Zhengzhou-Putian section of Longxi-Haizhou railroad, China. Pedosphere 19 (1), 121-128.

Mohiuddin, K., Strezov, V., Nelson, P.F., Stelcer, E., Evans, T., 2014. Mass and elemental distributions of atmospheric particles nearby blast furnace and electric arc furnace operated industrial areas in Australia. Sci. Total Environ. 487, 323-334. 
Motto, H.L., Daines, R.H., Chilko, D.M., Motto, C.K., 1970. Lead in soils and plants: its relation to traffic volume and proximity to highways. Environ. Sci. Technol. 4, 231-237.

Münch, D., 1993. Content profiles of arsenic, cadmium, chromium, copper, lead, mercury, nickel, zinc, vanadium and polynuclear aromatic hydrocarbons (PAH) in forest soil beside an urban road. Sci. Total Environ. 138, 47-55.

Nabulo, G., Oryem-Origa, H., Diamond, M., 2006. Assessment of lead, cadmium, and zinc contamination of roadside soils, surface films, and vegetables in Kampala City, Uganda. Environ. Res. 101 (1), 42-52.

Othman, I., Al-Oudat, M., Al-Masri, M.S., 1997. Lead levels in roadside soils and vegetation of Damascus city. Sci. Total Environ. 207 (1), 43-48.

Sheng, J.J., Wang, X.P., Gong, P., Tian, L.D., Yao, T.D., 2012. Heavy metals of the Tibetan top soils. Environ. Sci. Pollut. Res. 19 (8), 3362-3370.

State Development Center for Green-Food of China, 2000. Environmental Technical Terms for Green Food Production Area (NY/T391-2000) (Chinese).

Suzuki, K., Yabuki, T., Ono, Y., 2009. Roadside Rhododendron pulchrum leaves as bioindicators of heavy metal pollution in traffic areas of Okayama, Japan. Environ. Monit. Assess. 149 (1-4), 133-141.

Thorpe, A., Harrison, R.M., 2008. Sources and properties of non-exhaust particulate matter from road traffic: a review. Sci. Total Environ. 400, 270-282.

Van Bohemen, H.D., Van De Laak, W.H.J., 2003. The influence of road infrastructure and traffic on soil, water, and air quality. Environ. Manag. 31 (1), 0050-0068.

Viard, B., Pihan, F., Promeyrat, S., Pihan, J.C., 2004. Integrated assessment of heavy metal $(\mathrm{Pb}, \mathrm{Zn}, \mathrm{Cd})$ highway pollution: bioaccumulation in soil, Graminaceae and land snails. Chemosphere 55 (10), 1349-1359.

Wang, M.E., Markert, B., Chen, W.P., Peng, C., Ouyang, Z.Y., 2012. Identification of heavy metal pollutants using multivariate analysis and effects of land uses on their accumulation in urban soils in Beijing, China. Environ. Monit. Assess. 184 (10), 5889-5897.

Wang, G.X., Yan, X.D., Zhang, F., Zeng, C., Gao, D., 2013. Traffic-related trace element accumulation in roadside soils and wild grasses in the Qinghai-Tibet Plateau, China. Int J. Environ. Res. Public Health 11 (1), 456-472.

Werkenthin, M., Kluge, B., Wessolek, G., 2014. Metals in European roadside soils and soil solution-a review. Environ. Pollut. 189, 98-110.

Wheeler, G.L., Rolfe, G.L., 1970. The relationship between daily traffic volume and the distribution of lead in roadside soil and vegetation. Environ. Pollut. 18 (4), 265-274 (1979).
Wiseman, C.L.S., Zereini, F., Püttmann, W., 2013. Traffic-related trace element fate and uptake by plants cultivated in roadside soils in Toronto, Canada. Sci. Total Environ. 442, 86-95.

Wiseman, C.L.S., Zereini, F., Püttmann, W., 2014. Metal translocation patterns in Solanum melongena grown in close proximity to traffic. Environ. Sci. Pollut. Res. 21 (2), 1572-1581.

Wu, S.H., Zhou, S.L., Li, X.G., Jackson, T., Zhu, Q., 2011. An approach to partition the anthropogenic and natural components of heavy metal accumulations in roadside agricultural soil. Environ. Monit. Assess. 173 (1-4), 871-881.

Yan, X.D., Gao, D., Zhang, F., Zeng, C., Xiang, W., Zhang, M., 2013. Relationships between heavy metal contents in roadside topsoil and distance to road edge based on field observations in the Qinghai-Tibet Plateau, China. Int. J. Environ. Res. Public Health 10 (3), 762-775.

Yu, B.H., Lv, C.H., 2011. Assessment of ecological vulnerability on the Tibetan Plateau. Geogr. Res. 30 (12), 2289-2295 (Chinese).

Zaharescu, D.G., Hooda, P.S., Soler, A.P., Fernandez, J., Burghelea, C.I., 2009. Trace metals and their source in the catchment of the high altitude Lake Respomuso, Central Pyrenees. Sci. Total Environ. 407, 3546-3553.

Zehetner, F., Rosenfellner, U., Mentler, A., Gerzabek, M.H., 2009. Distribution of road salt residues, heavy metals and polycyclic aromatic hydrocarbons across a highway-forest interface. Water Air Soil Pollut. 198 (1-4), 125-132.

Zhang, H., 2013. The analysis on the enrichment of traffic-related heavy metals in soils and plants in the Tibet plateau. (dissertation). University of Chinese Academy of Sciences, Beijing.

Zhang, X.P., Deng, W., Yang, X.M., 2002. The background contents of 13 soil trace elements and their relationships to parent materials and vegetation in Xizang (Tibet), China. J. Asian Earth Sci. 21 (2), 167-174.

Zhang, H., Wang, Z.F., Zhang, Y.L., Hu, Z.J., 2012. The effects of the Qinghai-Tibet railway on heavy metals enrichment in soils. Sci. Total Environ. 439, 240-248.

Zhong, L.F., Li, J., Yan, W., Tu, X.L., Huang, W.X., Zhang, X.H., 2012. Platinum-group and other traffic-related heavy metal contamination in road sediment, Guangzhou China. J. Soil Sedimentol. 12 (6), 942-951.

Zuo, S.X., 2011. Research on identification of hazardous locations and countermeasure of Qinghai-Tibet highway. (dissertation), Jilin University, Ji Lin (Chinese). 